Имея в виду доминирующий сегментный и суперсегментный материал данных комплектов учебников, мы пришли к выводу, что центральное место отдается звукам [ч'], [j], [ш':], [ж], [ш], [ц], [л] и [ы], которые мы назвали фонетическим стереотипом. Мы считаем, что хотя и важно овладеть данными звуками, они по количеству и частотности не должны занимать центральное место. Они традиционно занимали центральное место в учебниках старшего поколения; учебники нового поколения, продолжая опыт предыдущих учебников, снова отводят им слишком значительное место. И в русском и в сербском языках присутствует большинство приведенных звуков, различие заключается лишь в качестве. Нужно, конечно, обращать на это внимание учеников. Современные учебники должны уделить особое внимание количеству и частоте употребления следующего фонетического материала: оппозиции твердый/мягкий согласный, ударный/редуцированный гласный, ИК-3 и типичному синтагматическому членению в высказываниях русского языка. Приведненные особенности русской артикуляционной базы очень трудно усваиваются носителями сербского языка, ибо в сербском языке они отсутствуют.
Нина Говедар ${ }^{1}$

Универзитет у Бањој Луци

821.163.41.09-31 Андрић И.

Филолошки факултет

https://doi.org/10.18485/mks_knsjkk.2017.ch6

\section{НАРАТОЛОШКИ ПРИСТУП РОМАНУ ПРОКЛЕТА АВЛИЈА У УНИВЕРЗИТЕТСКОЈ НАСТАВИ И МОГУЋНОСТИ ИНТЕРПРЕТАЦИЈЕ У СРЕДЊОШКОЛСКОЈ НАСТАВИ}

У овом раду ћемо се бавити могућностима тумачења романа Проклет̄а авлија са аспекта посткласичне наратологије, те разматрањем различитих аспеката које такав приступ омогућава при интерпретацији дјела у универзитетској настави. Своје интересовање усмјеравамо на могућности рада са студентима студијских програма за српски језик и књижевност, наставничког смијера. Циљ нам је да сагледамо што више могућности за што квалитетнију интерпретацију наведеног књижевног дјела у универзитетској настави. Такође, у раду ћемо се посебно осврнути на могућности методичке интерпретације романа Проклейа авлијау средњошколској настави, а на основу датог наратолошког тумачења.

Кључне ријечи: Проклет̄а авлија, когнитивна наратологија, могућности тумачења, универзитетска настава, средњошколска настава, наставна интерпретација књижевног дјела.

\section{1. Увод}

Књижевно дјело Иве Андрића свакако је један од најзначајнијих сегмената наше књижевне баштине. Својим вишеструким литерарним, естетским и универзално-животним вриједностима и дан-данас једнако привлачи и читаоце и проучаваоце. Вишеслојност коју његова дјела носе као општу одлику допушта нам да им приђемо са небројено много аспеката, откривајући сваки пут нове вриједности и нове могућности за тумачење.

Један од таквих приступа који се развио у савременом посттеоријском (према Иглтону), односно посткласичном (према Херману), виртуелној реалности окренутом друштву, јесте пост-

\footnotetext{
${ }^{1}$ nina.govedar@flf.unibl.org
} 
класична наратологија. Њен развојни пут темељи се на јачању и примјени нових технологија и методологија, кретању изван самих литерарних наратива и проширивању наратологије на нове медије и „наративне логике” (Милутиновић 2014: 360). У том контексту, ми смо се одлучили за представљање могућности наратолошког приступа у кључу посткласичне наратолошке праксе роману Проклетиа авлија у универзитетској настави књижевности, из чега произилазе могућности методичке апликације ове теорије на наставу у средњој школи.

\section{2. Наставна интерпретација у универзитетској настави}

Будући да тумачењу Проклетее авлије на универзитетском нивоу приступамо у кључу когнитивне наратологије, студенте је првенствено потребно упознати са основним теоријским значајкама које доноси посткласични приступ у оквиру когнитивних истраживања наратива. Основне елементе теорије, на које је потребно упутити студенте, како би се припремили за час на коме ће се тумачити књижевно дјело, дајемо у одјељку 2.1. даље у раду.

Како би се студенти мотивисали за самостално истраживачко читање и што квалитетније тумачење текста, потребно је усмјерити њихову читалачку пажњу ка одређеним елементима који ће бити у центру проучавалачке пажње на самој настави. Најбољи начин да то постигнемо јесте да формулишемо смјернице, односно истраживачке задатке који ће студентима бити нека врста водиље кроз дјело. ${ }^{2}$ У складу с тим, у наставку наводимо могуће задатке за истраживачко читање и тумачење Проклеие авлије у универзитетској настави.

\footnotetext{
2 Према наставним програмима већине факултета у региону на којима се изучава српска књижевност, Проклетиу авлију студенти читају у оквиру предмета који се бави српском књижевношћу 20. вијека, који је најчешће дио програма четврте године студија. Ово напомињемо будући да су студенти четврте године већ увелико оспособљени за самосталан истраживачки приступ књижевним дјелима, те да посједују основна знања из савремених књижевних теорија. У складу са овим претпоставкама, студентима треба дати задатке који ће им представљати за један нов и другачији приступ књижевном дјелу. Такође, важно је имати на уму да су се студенти са овим дјелом читалачки сусрели најмање једном раније (у средњој школи), те да одређена сазнања о елементима књижевног дјела (као што су структура, композиција, ликови, просторно-временски односи и идеје у дјелу) већ посједују.
}

- Присјетите се на који начин се из структуралистичке праксе развијају наратолошка истраживања. Дефинишите значајне домете у истраживању наратива највећих представника класичне наратолошке школе (Жерар Женет, Мике Бал, Шломит Кимон Ренан и др.). - Запазите које то новине у проучавању наратива доноси посткласични наратолошки приступ. - Када су у питању когнитивна наратолошка истраживања, она се наслањају на постигнућа одређених природних наука. Образложите на који су начин испитивања когнитивних процеса у природним наукама допринијела развоју наратолошке теоријске мисли. - Наведите најзначајније појмове који произилазе из савремених наратолошких проучавања.

- Читајући роман, обратите пажњу на приповједне низове из којих се састоји. - Установите колико се различитих приповједача јавља и именујте их. - Примијетите који од приповједача отвара приповједни круг. Зашто о доживљајима фра Петра приповиједа непознати младић, а не он сам? - Образложите шта аутор постиже увођењем објективног приповједача који о догађајима у Авлији приповиједа према туђем сјећању. - Запазите какви су Петрови ставови о причи и причању. - За кога од ликова-приповједача из дјела можете везати те ставове? - Примијетите како фра Петар описује Заимово и Хаимово приповиједање. - Образложите сличности и разлике између ова два лика и њиховох причања.

- Запазите како Ћамил приступа фра Петру. Окарактеришите његово приповиједање о судбини Џем султана. - Примијетите у ком тренутку и зашто се Ћамилов начин приповиједања мијења - Образложите зашто кажемо да је Ћамил приповједач чије причање стоји на граници реалног, исповједног и историографског.

- Дефинишите појам виртуелног наратива. - Примијетите у којим се све приповиједањима ликова из Проклеие авлије јављају могућности за конституисање виртуелног наратива. - Образложите у чему се огледа виртуелност у сваком од појединачних наратива у дјелу. - Закључите шта происходи као поетичка одлика дјела из таквих процјепа и како се они све манифестују.

\section{1. Когнитивна наратологија и виртуелни наратив}

За разлику од постструктуралистичке наратологије, која наративу прилази као затвореном и јасно дефинисаном конструкту носиоца приче, посткласична наратолошка истраживања окрећу 
се проучавању управо оних аспеката наративности које су њихови претходници узимали здраво за готово. Наиме, док су се класични наратолози бавили, прије свега, дефинисањем самог појма наратива и његових особина, маркирањем позиција које за разумијевање одређеног наратива могу бити од значаја (наратор - онај који приповиједа, фокализатор - онај који види, наратер - онај коме се приповиједа, итд) и њиховим међусобним односима, савремена наратологија се ослања на сазнања природних наука о комплексности когнитивних процеса, те проширује своје поље истраживања.

Класична наратологија првенствено је одвајала приповиједање од дјелања (текст или причу од представе или извођења), дефинишући наратив као приповиједни низ који у себи садржи најмање један догађај, да би каснији теоретичали заступали став како наратив мора садржати најмање два догађаја, и то повезана истим субјектом, односно представљати јединствену цјелину (Принс 2011: 154-155). Врло брзо, ипак, теоретичари наратива одбацују став Жерара Женета да извођење одређеног низа догађаја није наратив, те укључују (првенствено) филм и позоришну игру у своја истраживања ${ }^{3}$. Савремена наратологија данас подразумијева и филм и драму, рачунарске игре и свијет виртуелне реалности у својим проучавањима. Штавише, теоретичари данас наратив дефинишу као било какву условљену, цјеловиту догађајност, ослањајући се на теорију могућих свјетова и Бодријаров појам симулакрума, према којима наратив не мора ни на који начин да се реализује у стварности, тј. може да буде дио менталних процеса, у коначници, само замишљен или виртуелно конструисан, а не нужно и исприповиједан. Моника Флудерник (Fludernik) дефинише наратив као „репрезентацију могућег свијета у језичком и/или визуелном медију, у чијем је центру један или више протагониста антропоморфних карактеристика који су егзистенцијално увезани у временском и просторном смислу и коју (углавном) дјелају према одређеном циљу (радња и заплет)“ (2009: 6).

\footnotetext{
${ }^{3}$ Абот наводи како би искључивост одређених теоретичара да без наратора нема ни наратива искључивала драму и филм, који приповиједају догађаје иако најчешће немају наратора (2009: 361).
}

\section{2. Наративност у роману Проклейа авлија}

Теорија могућих свјетова почива на семантичкој логици да је свијет чији смо дио нужно централизован према свачијој појединачној идеји стварност, а на чијој се периферији налазе туђа виђења стварности ${ }^{4}$. Према Мари Лор Рајан (Ryan), примјењивост овог модела доживљаја свијета може се транспоновати на текстуалне свјетове пројектујући дистинкцију стварно/могуће, при чему се суштина доживљаја текста темељи на разликовању његовог актуелног домена и домена менталних активности ликова (2001: 103). Уколико у том контексту тумачимо оквир романа Проклетиа авлија у коме нам имплицитни аутор ${ }^{5}$ даје слику фра Петрове самостанске ћелије, крај чијег прозора младић посматра његов гроб у снијегу ${ }^{6}$, и присјећа се фра Петрових причања о свом боравку у Цариграду, можемо констатовати како је све, осим ове оквирне приче коју нам приповиједа имплицитни аутор, заправо виртуелни наратив, јер све јесте дио младићевих присјећања. ${ }^{7}$ Он је својеврстан посредник у току нарације, и уколико се присјетимо неке од многих схематизација наративних кругова унутар романа, закључујемо да је заправо, што се више ближимо централној приповијести, степен поузданости нарације потенцијално мањи. Наиме, будући да младић непосредно слуша фра Петрове приче, евидентно је да би тај наративни слој требало да буде најаутентичнији и најпоузданији. Међутим, чак и ту нам аутор оставља простора за преиспитивање приповједачеве поузданости реченицом: „Наравно да је при таквом начину причања остало доста празнина и необјашњених места, а младићу је било незгодно да прекида причање, да се враћа на њих и поставља питања“ (Андрић 1988: 19). Све приче у роману читалац сазнаје

\footnotetext{
${ }^{4}$ Више о овом питању види у Rуan 2001: 101-102.

${ }^{5}$ Код Вејна Бута, у контексту неоаристотелизма чикашке школе, означава „друго ја” стварног аутора.

${ }^{6}$ Из ове позиције дата је и уводна слика гробља прекривеног снијегом, чиме имплицитни/свезнајући аутор преузима фокализацију младића крај прозора.

${ }^{7}$ Снежана Милосављевић Милић их, према Мари Лор Рајан и Алану Палмеру, именује уметнутим причама и констатује како се може рећи да је „роман испричан техником йсихонаращије, изузимајући његове оквирне делове” (Милосављевић Милић
} 2016: 206). 
посредно - преко фра Петра. Како већину тих наратива младић евоцира у свом сјећању према сажетом и испрекидном фратровом причању, његовом приповиједању се нужно приписује елиптичност и претпоставља изостављање одређених наративних елемената који консеквентно код читаоца активира потребу за допуном процјепа и неизречених дијелова наратива. Милосављевић Милић наводи како „Виртуелни карактер садржаја ове приче није само последица елипсе и процепа већ је додатно интензивиран итерацијама које такође траже актуелизацију из дискурса изостављених делова. Ауторско тумачење фра Петрове приче парадигматично је својство свих каснијих прича, пре свега, њихове неактуелизоване димензије" (2016: 209).

Управо се на овом мјесту отвара могућност урањања, односно покушаја актуелизовања и тумачења виртуелног аспекта наратива за читаоца. Наиме, наша рецепција одређеног текста условљена је самим његовим садржајем, али и нашом способношћу као читаоца да препознамо његове различите слојеве, односно да разликујемо догађајност о којој неко приповиједа и потенцијалне „менталне моделе” о различитим догађајностима које могу бити експлицитно или иплицитно уткане у текст. У свом истраживању Дејвид Херман (Herman) се ослања на чињеницу да је онтолошка вриједност наратива једнака и кад је у питању приповиједање и дјелање, односно да се он на једнаке начине остварује како у вербалним, тако и у невербалним чиновима (Herman 2004: 171).

Више пута у роману и сам хетеродијегетички приповједач отворено констатује како је заправо више казано него што је читаоцу предочено: „Ово је само окосница Ћамилове приче, штуро и кратко казана” (Андрић 1988: 64), односно како онај наратор који првобитни наратив прелама (у овом случају је то експлицитно фра Петар, а затим имплицитно и младић крај прозора) нешто и прећути, скрати, изостави или сажме. Ту недореченост једним дијелом изазива околина која је непријатељска, завјереничка и исљедничка, а са друге стране она је неминовност наративности као такве. Сваки је наратив вјештачки конструкт, без обзира на то да ли препричавамо неки догађај који се десио или наше приповиједање проистиче из неке врсте конструисане реалности. Виртуелни наратив, на том трагу, можемо посматрати у контекту теорије Мери Лор Рајан, која дефинише два његова аспекта - виртуелни наратив као могући дио постојеће приповијести и виртуелност наратива као лажну наративну путању (Милосављевић Милић 2014: 339).

Виртуелне реалности постоје у свим наративима започетим у Проклешиој авлији. Заим „говори тихо али сигурно и одушевљено, а говори увек о себи и казује све само у крупним потезима Прича увек о истој ствари и толико је увеличава и умножава да би требало бар сто педесет година живота да један човек све то доживи” (Андрић 1988: 22), док се за Хаима каже да се „видело да говори више због себе, што не може друкчије, него због оног што говори и оних којима говори” и да је „његова потреба за говором била већа и јача од његове невоље и великог стаха", те на концу да „ту где се завршавало једно, почињало је друго причање. Краја није било" (Андрић 1988: 44), постављајући га тако у положај архетипског приповједача коме живот зависи од приче и чије приповиједање никада не стаје, већ се једна прича одмах надовезује на другу. Његов газ у виртуелно највише се одражава у коментару да је „Хаим све знао, и видео и оно што се није могло видети” (Андрић 1988: 70).

И Ћамил је приповједач чије причање стоји на граници реалног, доживљеног и исповједног и историографског, чиме он заузима позицију актера сопственог виртуелног наратива. Како наводи Милосављевић Милић „Унутар миметичког контекста Ћамилова прича је натурализована психолошком мотивацијом, као симптомом патолошког стања" (2016: 212). Ипак, без обзира на то колико луцидно дјеловало ово увлачење себе самог у наративни дискурс, односно пројектовање себе у постојећи наратив, у контексту уланчаних приповиједања, ово Ћамилово заправо остварује савршенство миметичког приповиједања, у коме приповиједач и прича постану једно. Док се Хаим плаши свих и свега око себе, и свачију трагичну причу доживи врло лично, али је врло брзо и заборави, Ћамил је опсједнут једном причом, једним наративом, чији дио постаје. У истом тренутку он остварује три метапозиције: читаоца историографског штива, наратора повијести о Џем султану и лика о коме се приповиједа, односно Џем султана самог. У том контексту је и сљедећи приповједачев ко- 
ментар: „Оно што није, што не може и што не треба да буде било је јаче од оног што јесте и што постоји, очигледно, стварно и једино могуће" (Андрић 1988: 67).

\section{3. Простор и вријеме}

Свако фра Петрово ново причање у роману најављује звук часовника који откуцавају. У дјелу се стално инсистира на подвојености временских слиједова - једно, стварносно вријеме (механичко) означавају и представљају управо ови часовници који откуцавају у времену када младић слуша фра Петрове приче; друго је вријеме саме приповијести, вријеме које граничи са митским, које има неки свој почетак и крај, независно од времена које паралелно тече у реалности. Контекст сазнавања наратива дефинишу простор и вријеме приповиједања (не догађања!). У овом роману, стога, јавља се, поред овог митског које их све спаја, и неколико индивидуалних времена, која протичу сама за себе.

Сви приповиједни кругови, осим иницијалног, отварају се у том „ђаволском острву, изван свега што је до тада значило [за њега] живот" (Андрић 1988: 24), међутим, само Хаимово приповиједање проистиче из Авлије и завршава се са Авлијом и њеним становницима као главним актерима. Једино се он као приповиједач у потпуности поистовећује са својом улогом свезнајућег наратора и хроничара Авлије - онога који о свему све зна, чак и оно што се не може знати. Онога тренутка када Ћамила одведу из Авлије и он престаје да се интересује за његову судбину, и узалуд фра Петар покушава са њим да започне разговор о Ћамил ефендији - Џем султану. Самим тим, Хаим постоји само у контексту боравка у Проклетој авлији, он као лик и као личност не постоји мимо ње.

O Ћамилу, са друге стране, сазнајемо читаву сторију - једнако као и о његовом Џем султану. Сазнајемо (од Хаима) и његово поријекло, његов животни пут и разлог зашто је доведен у Авлију. Чак и архетипске појединости које ће га довести у најповршнију везу са јунаком својих историјских истраживања - обојици су мајке биле хришћанке. Прича о Ћамилу исприповиједана је хронолошки, са много детаља (опет детаља које није било могуће знати), а на њу се надовезује Ђамилово причање фра Петру о не- срећној судбини младог султана, која је хронолошки дата у грубим цртама, да би затим „почело причање издвојених призора са свим појединостима“ и након чега фра Петар „није одмах ни право приметио тренутак, тешки и одлучни тренутак, у коме је Ћамил јасно и први пут са посредног причања туђе судбине прешао на тон личне исповести и стао да говори у првом лицу“ (Андрић 1988: 66). Управо је то тренутак у роману када се спајају временске и просторне вертикале и млади Турчин из Смирне једном рјечју - „ја”, зарања у сопствени виртуелни наратив. Његова приповијест о Џем султану дата је хронолошки, ослањајући се на литературу коју млади Ћамил опсесивно проучава. Ипак, у његовом причању с времена на вријеме појављују се наговјештаји да младић из Смирне и Џем султан дијеле доста тога заједничког. У тренутку када се унутар сопствене приповијести Ђамил поистовијети са несрећним султаном, долази до коначне манифестације његовог патолошког стања, које је мотивисано у самој његовој историји (Џаџић 1997: 93).

\section{3. Могућности наставне интерпретације у средњој школи}

Роман Проклешиа авлија Иве Андрића према наставном програму обрађује се у четвртом разреду средње школе. Према наставном програму, од ученика четвртог разреда очекује се да разумију обиљежја савремене књижевности, самостално интерпретирају књижевне текстове и изводе закључке о карактеристикама пјесничког језика, мотива и форми (НПП 2014: 18). Наставна интерпретација романа Проклейа авлија требало би управо да омогући ученицима самосталнији приступ тексту, разумијевање специфичне структуре романа, самостално препознавање најзначајнијих мотива и однос између ликова и нарације. Стога се наставни циљеви проучавања овог романа могу дефинисати на сљедећи начин:

Образовни циљеви: Мотивисање ученика за читање, доживљавање и проучавање романа Проклетиа авлија. Упознавање са специфичном структуром романа. Сагледавање поетских карактеристика Андрићевог дјела и тумачење његових поетичких ставова о причи и причању. Маркирање карактеристика ликова који се налазе у стамболском затвору са фра Петром и њихових опсе- 
сивних тема. Дефинисање улоге приповједача у роману и препознавање специфичних приповједних позиција на којима се сваки од приповједача-ликова налази. Навести ученике да спознају и освијесте структуру романа кроз приповједачке кругове, те да исту представе кроз графичку скицу.

Проучити просторне позиције које су дефинисане у роману и припадност појединих приповједача-ликова одређеном простору. Тумачити временску неодређеност романа у контекту универзалности његове предметности. Аналитички приступити дефинисању специфичних одлика приповиједања ликова (фра Петар, Хаим, Заим, Ћамил), те тумачити неодређености у њиховим наративима. Тумачити наративне слиједове у роману у контексту Андрићевог става о причи и причању. На примјерима из романа поткријепити став о Хаиму као архетипском приповједачу (разговарати са ученицима о темама Хаимових причања, његовим побудама за причом и специфичношћу његових наратива). Аналитички тумачити Ћамилов лик и његову опсесију личношћу Џем султана. Навести ученике да закључе зашто се и на основу чега Ђамил поистовјећује са младим султаном. Истражити Заимове опсесивне приповиједне теме. Анализирати са ученицима особине његових наратива и приповједачког поступка.

Васпитни циљеви: Кроз разговор са ученицима сагледати и образложити умјетничко богатство романа. Анализирати значај причања и комуникације у животу сваког појединца. Тумачити идејно богатство дјела. Разговарати са ученицима о лику Карађоза и навести ученике да процјењују његов лик са психолошког и моралног аспекта. Тумачити животне околности из прошлости ликова које се у роману наводе као узрок његових ставова и понашања у садашњости. Навести ученике на морално просуђивање поступака одређених ликова. Анализирати однос фра Петра и Хаима у стамболском затвору, те разматрати са ученицима људску потребу за друштвом и дружењем у свим животним ситуацијама. Кроз лик Заима тумачити посљедице лажи и претјеривања у причању, те навести ученике да закључе како се остали односе према Заиму када спознају ове његове особине. Тумачити узроке који главне ликове доводе у Проклету авлију, те са ученицима разговарати о проблему кривице и значају праведног поступања. Посебно се осврнути на кривицу која се приписује фра Петру и Ћамилу и поредити страдања интелектуалца са другим дјелима која су ученицима блиска.
Функционални циљеви: Навести ученике да се активно уживе у умјетнички свијет књижевног дјела. Навикавати их на што самосталнији приступ књижевном тексту. Подстицати ученике на активно истраживачко читање са биљежењем. Његовати истраживачки и аналитички приступ књижевном тексту. Подстицати код ученика аргументован приступ анализи књижевног дјела и његових структуралних елемената. Разговарати са ученицима о естетским вриједностима дјела које су их посебно узбудиле. Навести ученике да одређене аспекте дјела сагледају у контексту моралног и правичног поступања. Подстицати их да дефинишу особености наратива са којима су се сусрели у роману и да их упореде са разговорима које свакодневно слушају. Освијетлити процјепе, недореченост и виртуелност наратива у роману у контексту свакодневне комуникације која је ученицима блиска. Навести ученике да закључују чему доприносе овакви поступци у књижевности. Наводити ученике на препознавање и тумачење одлика савременог романа. Сагледати роман у контексту српске књижевности половином 20. вијека и у контексту Андрићевог стваралаштва. Навести ученике да неке од естетских вриједности дјела упореде са другим пишчевим дјелима. Побуђивати интересовање за читањем и доживљавањем и осталих Андрићевих дјела.

Прије читања књижевног дјела ученике треба истраживачким задацима упутити на што дубље и свестраније уживљавање у умјетнички свијет дјела и усмјерити њихову читалачку пажњу ка елементима који су важни за тумачење дјела и који ће на часу бити предмет анализе. Истраживачки задаци треба да буду конципирани тако да усмјеравају ученичку пажњу током читања и побуђују на промишљање о дјелу. Будући да у овом дијелу рада говоримо о могућностима методичке апликације наративног приступа роману, у наставку ћемо предложити модел истраживачких задатака који ученицима може да буде водич при тумачењу управо наративних сегмената.

- Уживите се у умјетнички свијет романа Проклейа авлија Сагледајте из чије перспективе сазнајемо о дешавањимо у Авлији? - Замислите простор стамболског затвора у коме се „стварају тихи или гласни кругови”. Око кога се ствара први круг који срећемо у дјелу? - Окарактеришите Заимово приповиједање. Шта вам је у 
вези с њим посебно упечатљиво. - Примијетите у каквом односу стоје Заимово приповиједање (које је такво да би „требало бар сто педесет година да један човјек то доживи”) и начин његовог живота, односно разлог зашто је доведен у Авлију.

- Уочите како се упознају фра Петар и Хаим, Јеврејин из Смирне. - Обратите пажњу на то како фра Петар доживљава Хаима и његово причање. Шта је у вези с њим упечатљиво? - Наведите најизраженије карактеристике Хаимовог приповиједања - Запазите о чему Хаим нашироко приповиједа фра Петру и како је дата историја младића из Смирне.

- Примијетите како се воде разговори између фра Петра и Ћамила. 0 чему разговарају двојица затвореника и ко је у разговору отворенији и говорљивији? - Запазите како Ћамил почиње своју причу о Џем султану. - Примијетите на који начин је ова повијест дата у дјелу, а како ју је фра Петар чуо од Ћамила. - Образложите зашто се каже да је читаоцу представљена само окосница Ћамилове приче.

- Обратите пажњу на то када се и како Ћамилово приповиједање мијења. О чему он говори фра Петру након што је завршио са приповиједањем цијеле историје о Џем султану. - Запазите како се завршава Ћамилова прича о Џем султану. Да ли је исприповиједао све што је желио? - Окарактеришите младићев однос према јунаку своје приче. На којим се све нивоима он поистовјећује са младим султаном? - Размислите о томе зашто у једном тренутку Ћамил прелази на приповиједање у првом лицу и образложите овај његов поступак.

- Након Ћамиловог нестанка, у Авлији се наставља живот. Кругови се и даље окупљају око приповједача, Хаим свакодневно долази до фра Петра. - Обратите пажњу на Хаимово причање у овом тренутку. Које му теме окупирају мисли?

- Запазите коме се обраћа фра Петар када говори о својим диживљајима у Смирни. - Образложите ко је приповиједач који завршава приповијест о фра Петру у Проклетој авлији. Размислите о томе која је његова улога као приповједача. - Образложите зашто фра Петар није онај из чијих уста сазнајемо о његовом времену проведеном у Проклетом авлији. - Закључите каква би била разлика да је прича исприповиједана од стране фра Петра, а не према његовом сјећању. Којих елемената не би било у дјелу? - Образложите на који начин ауторски коментари доприносе самом дјелу и читаочевом доживљају и разумијевању.

\section{4. Закључак}

Будући да се студенти ријетко на основним студијама сусрећу са најсавременијим теоријским концептима, а и када за то имају прилику то подразумијева стицање основних знања о појединим теоријским струјањима или бављење њима кроз изборне курсеве (дакле, не на обавезним предметима које слушају сви студенти), овакав приступ књижевном дјелу, који подразумијева познавање основа одређеног књижевнотеоријског приступа, захтијева и конкретне истраживачке припремне активности студената. Наиме, према увиду који смо имали у програме већине факултета у региону (Бања Лука, Источно Сарајево, Београд Ниш, Нови Сад, Крагујевац) на којима се изучава књижевност (било српска, било општа, било нека од других националних књижевности) савремене књижевне теорије тек су овлаш обухваћене предметима који су категорисани као обавезни, и у најбољем случају обухватају зачетак постструктуралистичке промјене парадигме.

Стога би студентима као припремне задатке за овакав начин изучавања романа Проклеш̄ авлија требало дати врло конкретне смјернице о основној литератури са којом треба да се упознају, али и прије самог изучавања књижевног текста са њима разговарати о усвојеним новим знањима и могућностима њихове примјене у широком контексту изучавања књижевности уопште. Заједно са великим бројем квалитетних студија и критика написаних о овом роману, на које свакако треба упутити студенте, те увођењем савременијих књижевних приступа, остварује се цјеловит сазнајно-интерпретативни процес, који у сваком случају доноси ново, свестраније и квалитетније тумачење овог књижевног дјела.

Иако књижевне теорије 20. вијека стоје као темељ савременог проучавања књижевности, вјерујемо како би било више него сврсисходно студенте упутити на актуелне теорије (не само књижевне него културолошке, уопште), како бисмо им дали неку врсту смјернице и стручног упућивања за даље самообразовање. За разлику од основне и средње школе, гдје се са̂мо књижевно дјело налази у средиштву наставе књижевности (Бајић 2007: 147), у 
универзитетској настави примат се даје теорији и историји књижевности, управо из разлога утемељења различитих методолошких приступа проучавању књижевности. Да би студенти били спремни да сутра у учионици мотивишу ученике на усвајање нових знања и тумачење нових књижевних дјела, наша је обавеза да их за то обучимо. Стога, не само да је значајно у факултетску наставу уводити нову методологију и приступе проучавању књижевних дјела, него је неопходно студентима пластично и врло конкретно показати на који начин новоусвојена знања могу примијенити у основношколској или средњошколској настави, развијајући са њима различите могућности методичке апликације усвојених знања. Ажурно, конкретно и сврсисходно повезивање књижевне и наставне теорије, један је од изузетно битних начина сталног унапређивања теоријских сазнања методике наставе књижевности и, коначно, самог наставног процеса.

\section{ЦИТИРАНА ЛИТЕРАТУРА}

Абот, Х. П. Увоg у шееорију йрозе. Београд: Службени гласник, 2009.

Бајић, Љ. „Рецепција и деловање књижевног текста на ученика.” Норма: образоване учииееља јуче, яанас, суйра. Год. 12, бр. 1 (2007): 147-156.

Милосављевић Милић, С. „Редефинисање наратива у посткласич-

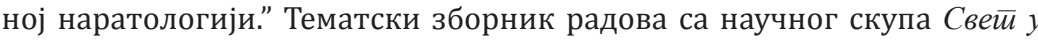

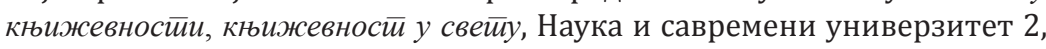
II том. Ниш: Филозофски факултет, 2014

Милутиновић, Д. „Посткласична наратологија.” Тематски зборник

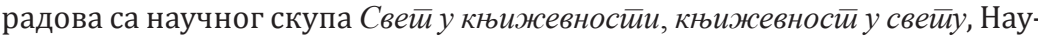
ка и савремени универзитет 2, II том. Ниш: Филозофски факултет, 2014.

Насйавни ироірам за чейвриии разреg іимназије. Бања Лука: Министарство просвјете и културе, 2014.

Принс, Џ. Нарайолошки речник. Београд: Службени гласник, 2011.

Џаџић, П. О Проклешиој авлији. Београд: Завод за уџбенике и наставна средства, 1996.

Andrić, I. Most na Žepi; Prokleta avlija. Sarajevo: Svjetlost, 1988.

Milosavljević Milić S. Virtuelni narativ-ogledi iz kognitivne naratologije. Sremski Karlovci, Novi Sad: Izdavačka knjižernica Zorana Stojanovića, Niš: Filozofski fakultet, 2016.
Fludernik, M. An Introduction to Narratology. London and New York: Routledge, 2009.

Herman, D. Story Logic. Lincoln and London: University of Nebraska Press, 2004

Ryan, M-L. Narrative as Virtual Reality. Baltimore: The Johns Hopkins University Press, 2001

НАРРАТОЛОГИЧЕСКИЙ ПОДХОД К РОМАНУ

\section{«ПРОКЛЯТЫЙ ДВОР» В УНИВЕРСИТЕТСКОМ ПРЕПОДАВАНИИ И} ПРОИСТЕКАЮЩИЕ ВОЗМОЖНОСТИ ИНТЕРПРЕТАЦИИ ПРЕПОДАВАНИЯ В СРЕДНЕЙ ШКОЛЕ

В данной работе будем заниматься возможностями интерпретирования романа «Проклятый двор» с точки зрения когнитивной нарратологии, а также рассмотрим различные возможности, которые данный подход позволяет осуществить в интерпретации произведений в университетском преподавании. Наш интерес сосредоточен на возможностях работы со студентами учебных програм сербского языка и литературы, преподавательского направления. Наша цель состоит в том, чтобы рассмотреть как можно больше вариантов для наилучшей интерпретации указанного литературного произведения в университетском преподавании. Кроме того, в работе будут конкретно рассмотрены методологические возможности интерпретации романа «Проклятый двор» в преподавании в средней школе, основанные на данной нарратологической интерпретации. 